\title{
Shanthini Pillai*
}

\section{Unequal discursivities and the symbolic capital of Malaysian Indian scholarship}

https://doi.org/10.1515/ijsl-2020-0072

Received August 29, 2020; accepted November 20, 2020

\begin{abstract}
This paper engages with the aspects of discursive hegemony in terms of both Metropolitan and disciplinary position and privilege, using the sociology of the language that has been produced on Malaysian Indian identity as my point of reference. It contends that these observations and articulations are able to rise to the surface more easily when they are securely located within disciplinary domains often related to determinacy. I argue that viewed as a whole, it becomes apparent that these discourses are coloured by the subjective desire of the accumulation of knowledge on the subject matters of their writings. As such, they are as much stories that are told of the Malaysian Indian community as those found in literary narratives and can ultimately lead to unequal discursivities.
\end{abstract}

Keywords: cultural capital; Malaysian Indian; metropolitan hegemony; publishing privilege; unequal discursivities

Makalah ini membicarakan aspek-aspek hegemoni dari kedua- dua sudut kedudukan dan kelebihan Metropolitan serta disiplin, dengan menggunakan sosiologi bahasa yang terhasil dalam karya-karya berkaitan identiti kaum India di Malaysia yang menjadi tumpuan perbincangan. Ia berpendapat bahawa pemerhatian dan artikulasi ini boleh menyebabkan lebih mudah munculnya pandangan-pandangan seperti ini yang sebenarnya sudah terterap dalam domain disiplin yang sering terkait dengan ketetapan. Makalah ini membahaskan bahawa apabila dilihat secara menyeluruh, jelas sekali bahawa wacana-wacana seperti ini diwarnai oleh kehendak subjektif dalam akumulasi pengetahuan terhadap perkara yang dibincangkan dalam penulisan para pengkarya. Oleh yang demikian, pandangan-pandangan ini banyak dapat dilihat dalam lontaran-lontaran karya tentang masyarakat India di Malaysia sebagai mana juga yang terdapat dalam naratif sastera dan maka boleh menjanakan ketidakseimbangan diskursiviti.

Katakunci: modal budaya; Masyarakat India Malaysia; hegemoni Metropolitan; keistimewaan penerbitan; ketidakseimbangan diskursiviti

A Malay version of this article can be found in the Appendix.

*Corresponding author: Shanthini Pillai, National University of Malaysia, Bangi, Malaysia, E-mail: spillai@ukm.edu.my. https://orcid.org/0000-0002-7555-5698 
While we may have come far beyond the issue of the hegemony of communicative practices as a key factor in the marginalisation of scholars from developing countries, such as that argued by Canagarajah in the 1990s (Canagarajah 1996), the same paradigms of centre and margin in the circumference of knowledge production continue to emerge in different configurations. These in turn emphasise the contemporary relevance of Bordieu's argument on the triad of cultural capital, social capital and symbolic capital amassed by different fractions of the dominant class as they operate within fields of power and the topology of hierarchical spaces they generate (Bourdieu 1989: 16). The topology of the academic world is still governed by commanders of capital, those who make up the dominant classes by virtue of their positions in Metropolitan centres, fortified by the strength of global monetary systems and the higher value that certain currencies have over others. It is this primary financial capital that inherently allows researchers in the Global North means towards physical data retrieval in any given area of study. A cursory glance at the list of acknowledgements in many of the scholarly volumes from Metropolitan academic publishing houses will indubitably reveal multiple grants and research fellowship posts that facilitated travel for research fieldwork. Such grants play a key role in facilitating the accruing of cultural capital of communal ontologies across the globe, often in countries of the Global South where one's currency goes much farther. When these are then collated and published with Metropolitan university press houses with equally high currency in academic circles, ideas become institutionalized as they are distributed and consumed across global channels of communications. These inherently translate into Bourdieu's social capital, cultivating the fields of power, persuasively exercised in and through discourse, for with the relative weight of such capital gains on their side of the field, they ultimately become the heavyweights of academic discursive space. Yet, as all discourse is constituted by cognitive perception and when these are equally subject to the hegemony of the dominant (Bourdieu 1989: 18) they very easily become Metropolitan symbolic capital. It is this last point that especially informs the following discussion of the sociology of the ethnic markers of the Malaysian Tamil, as discourses become legitimised by the capital that they accrue, of the academic assets gained through discursive power facilitated by ease of access to publishing and the attendant dissemination of Metropolitan scholarly perceptions that give rise to unequal discursivities. In this way, as much as there can exist "unequal Englishes" (Tupas and Rubdy 2015) that prioritise and marginalize perceived differences in lingual articulation, then it follows that there surely can be unequal discursivities, as a host of observations and reflections can also rise to the surface more easily when they are securely located within disciplinary domains often related to determinacy and metropolitan privilege. In the following discussion, I engage with the aspect of unequal discursivity and the 
attendant symbolic capital they generate within the arena of both Metropolitan and disciplinary position and privilege, using the sociology of the language that has been produced on Malaysian Indian identity as my point of reference.

A majority of Malaysian Indians have an ancestral lineage that can be traced to the host of individuals who left the shores of South India in the nineteenth century primarily to escape famine and other oppressive socio-economic conditions, most notably influenced by information that was relayed about opportunities to work on the plantations, road and railroad projects that were primed for inception in the Malay Peninsula. Enquiries into this historical event and its attendant sociological experience have predominantly been read and reasoned out in the areas of history, economy and socio-political studies. These publications are often positioned as determinate productions of knowledge on Malaysian Tamils based on empirical evidence. Yet, if we were to take some time to look at the sociology of the language that has been produced about the Malaysian Indian then we will see that Indian migrants to Malaya have been incessantly portrayed as both commodity and casualty of colonial capitalist servitude, a direct response to the economic role they played. We hear of recruitment practices, settlement patterns, some indication of regional affiliation or ethnolinguistic composition and, largely, the manner in which Indians contributed to the capitalist economy of British Malaya. These are always poised, though, at the edge of what JanMohamed (1985) calls the manichean vortex of the colonialist cognitive framework (63). In the context of the sociology of the ethnic markers of the Malaysian Tamil, the strength of the currents generated by this vortex seems to inevitably steer writers into one of two directions. The first is caused by a reiteration of Malaysian Indians (or more particularly Malaysian Tamils) as perennial victims of circumstances that remain forever beyond their control. The second is caught up in the rapid flow towards ritualistic spiritual exuberance. These in turn place them back in dialogue with Said's (1978) notion of the immortality of Orientalism, especially in light of his standpoint that the western scholar's "shift away from the place of his residence to the scene of his scholarly reputation is the source of his great fame in the annals of Orientalism" (Said 2003 [1978]: 164).

Such hegemonic dynamics of the chronicle of the Malaysian Indian can be gleaned in the following example I use: that of contemporary American anthropologist, Andrew C Willford, based in the global North, who gains leverage from the cultural capital of his ethnographic research and consequent publications on Malaysian Tamils as part of the marginalised communities of the Global South. If we were to review the discursive dynamics of the semantic network reflected in the choice of titles for his two notable volumes on the community, as well as a host of other articles, the nodes of Orientalistic vocabulary, imagery and style of representation become very much evident; the regalia of accumulative symbolic capital 
become evident too. Each title strategically brackets the Malaysian Tamil within the currents of two opposing channels of meaning. In "Weapons of the meek": Ecstatic ritualism and strategic ecumenism among Tamil Hindus in Malaysia" (Willford 2002) the dialogics of each linguistic marker clearly signpost this traction. They may have weapons but, as they are characterised as meek, the semantic network negates their power. Power in turn is linked to passionate religiosity, which is clearly intangible. The referential meaning thus clearly points to inevitable failure in the material world, emphasized through a lexical network steeped in negation. Willford would proceed to publish the data gathered from his fieldwork among Malaysian Tamils as a book with a Metropolitan university press, with yet another dichotomously nuanced title, "Cage of freedom: Tamil identity and the ethnic fetish in Malaysia” (Willford 2006). Aspirations for liberation emerge impounded and identity is but a fixation. Coupled with this are the visual semiotics of the book cover, as it presents the steps of a famous Hindu Temple, densely packed with pilgrims during the annual festival of Thaipusam, dedicated to the God Murugan. Ascendence is thus accentuated only through religion for the Malaysian Tamil community. A decade later, Willford publishes yet another book, with a Metropolitan publisher, espousing similar nuanced language "Tamils and the haunting of justice: history and recognition in Malaysia's plantations" (Willford 2015), along with a cover page depicting Malaysian Indians on yet another pilgrimage based on their particular clothing, this time in a rural setting, with a laterite path captured in the background. If we view these publications as a whole, then it becomes apparent that they are bolstered by heavily nuanced representational discourse, coloured by the subjective desire of the accumulation of knowledge on the subject matters of their writings, thus very much mental structures of perception (Bourdieu 1989: 18), a discursive habitus. As Willford's discourse is predicated predominantly on the semantics of the ever-elusive arms of justice on the one hand, and on the other of the spiritual exaltation of the Malaysian Indian, they are in essence subjective sets of stories told by an anthropologist. It is this latter fact that links them to artistic cultural productions of the same subject matter, that of literary texts.

If, as Arjun Appadurai (2005: 52) notes, a new form of ethnography should "capture the impact of deterritorialization on the imaginative resources of lived, local experiences”, then literary narratives can play a significant role, especially through dialogic engagement with the material in the gaps and fissures cast aside by other disciplines in the resolve for facts and figures, as well as verbatim data. The validity of the vision of the literary form and its socio-cultural connections has remained integral to human developmental issues as far back as its inception as oral folklore. However, multi-levelled nuances of symbolic language often insinuate indeterminacy and this often closes off engagements of disciplinary dialogue. 
I would like to end on a comparative note of two passages on memory and the plight of the Malaysian Indian working class to illustrate a similar topology in the discursive habitus of representation reflected. The first is from Willford's recent volume on the Malaysian Tamils, whereas the second quotation is from a semiautobiographical novel by one of the pioneers of Malaysian Indian literature, KS Maniam:

Community leader P. Palanisamy was a dejected man when Naga and I interviewed him in 2006. He had lost all hope of a just settlement in a dispute between former plantation workers of Bukit Jalil Estate and the local government. He lamented that the new generation of city hall officials had no knowledge of the plantation folk's years of hardship and toil, nor of their attachment to the land. They also appeared ignorant of promises made to the workers by their predecessors. (Willford 2014: 1)

She divided her time between her vadai hand-cart and the Town Council Office, appealing for land ownership on the grounds that she had occupied that bit of land long enough to be its rightful heir.

"My many spirits roam it," she told me. "When I die, I'll never stop haunting the place." But she had no papers, only a vague belief and a dubious loyalty. The houses around hers were already being pulled down. Rafters, fallen beams and charred remains gaped like a death larger than Periathai's approaching demise whenever I went - and these occasions had grown fewer - to visit her. She refused to leave the house for fear that it might be demolished during her absence. (Maniam 1993 [1981]).

Both contain similar references to state rejection and its attendant feelings of dejection and the lack of formal documentation that impedes ownership of land. Maniam's novel was set in pre-independence Malaya and first published in 1981, while Willford's ethnographic story emerges from contemporary Malaysia of the millennium. Yet, there has not been a single reference to any of his works in Willford. These are the dialectics that stare at the subalternist cultural scholar like myself, researching the Indian working-class community, and dealing with challenges of and challenging discursive hegemony and exclusivity in the scholarly publishing circles. Ultimately, discussions in the various disciplines need to engage with each other when there is common ground so that every stone must be overturned so that we can imagine the lives of marginalised Malaysian Indians, and find too the nuances of agency and resistance to state power and will outside the intangible realm of ritual.

Acknowledgements: I would like to thank Dr Norwati Md Yusof for aiding with the translation of this article.

Research funding: This work was supported by The National University of Malaysia grant Code GUP-2019-056. 


\section{Appendix}

\section{Ketidakseimbangan diskorsitiviti dan modal simbolik dalam kesarjanaan kaum India Malaysia}

Isu hegemoni amalan komunikatif telah banyak dibicarakan sebagai faktor utama dalam peminggiran para sarjana dari negara-negara dunia ketiga dan perkara ini banyak didebatkan oleh Canagarajah dalam tahun 1990-an (Canagarajah 1996). Paradigma yang sama tentang pemusatan atau peminggiran dalam lingkaran pengkaryaan ilmu pengetahuan terus berlaku dan wujud dalam pelbagai konfigurasi. Hal ini seterusnya mewujudkan keperluan kontemporari seperti yang ditegaskan oleh Bordieu tentang segi tiga modal budaya, modal sosial dan modal simbolik yang timbul daripada pelbagai lapisan pihak yang dominan kerana mereka berfungsi dalam bidang-bidang kuasa dan pemetaan ruang-ruang hierarki yang dibentukkan oleh mereka sendiri. (Bourdieu 1989, hal. 16). Demikian juga pemetaan dunia akademik masih diurus tadbir oleh pihak-pihak pemacu modal. Mereka merupakan kelas dominan dalam masyarakat berdasarkan kedudukan mereka yang penting di pusat-pusat Metropolitan. Dengan status ini yang diperkukuhkan oleh sistem-sistem kewangan global dengan nilai-nilai mata wang yang lebih tinggi berbanding yang lain, maka modal kewangan primer seperti ini secara langsung meluluskan permohonan para penyelidik dari Utara Global terhadap penjejakan maklumat fizikal dalam mana-mana bidang pengajian. Tinjauan terhadap senarai penghargaan dalam kebanyakan penulisan kesarjanaan dari syarikat penerbitan akademik Metropolitan pastinya mendedahkan pelbagai geran dan zamalah penyelidikan yang memberi kemudahan mereka melakukan lawatan kerja lapangan untuk menjalankan penyelidikan. Geran sedemikian memainkan peranan utama dalam memudahkan terkumpulnya modal budaya secara semulajadi sesebuah masyarakat antarabangsa, terutamanya di negaranegara Global Selatan di mana nilai mata wang boleh lebih dimanfaatkan. Apabila diatur rapi dan diterbitkan oleh penerbit universiti Metropolitan yang sama-sama mempunyai mata wang nilai tinggi dalam kelompok akademik, pandangan tertentu terinstitusi dan tersebar serta digunakan dalam semua bentuk komunikasi global. Hal ini menjelaskan tentang pendapat Bourdieu: dengan modal sosial dan penjurusan bidang-bidang kuasa, selain kekerapan amalan dalam dan melalui wacana penulisan, serta dengan pertimbangan yang secukupnya akan pemilikan modal bagi bidang-bidang tertentu yang mereka ceburi, mereka akan akhirnya menjadi juara dalam lingkungan diskursif akademik. Namun, oleh kerana wacana akademik termaktub oleh persepsi kognitif dan apabila pandangan-pandangan ini tertakluk juga kepada hegemoni dominan (Bourdieu 1989, hal. 18), maka modal 
simbolik Metropolitan lebih mudah terbentuk. Modal simbolik inilah terutamanya yang menjadi tunjang perbincangan seterusnya dalam makalah ini tentang sosiologi penentu etnik Tamil Malaysia, kerana wacana akademik menjadi sah melalui modal terakru akan aset-aset akademik yang didapati melalui kuasa diskursif yang dipermudahkan melalui kelebihan mengakses penerbitan dan wujudnya penyebaran persepsi kesarjanaan Metropolitan sehingga menyebabkan munculnya ketidakseimbangan diskursiviti. Dengan cara ini, sebanyak mana pun wujud "ketidakseimbangan bahasa Inggeris" (unequal Englishes: Tupas dan Rubdy 2015) yang mengutamakan pemusatan atau peminggiran perbezaan pandangan dalam artikulasi lingual, lalu berikutan hal tersebut maka pasti boleh wujud juga ketidakseimbangan diskursiviti kerana pemerhatian dan pendapat juga boleh menyebabkan lebih mudah berlaku apabila pandangan-pandangan seperti ini kemas bertapak dalam domain disiplin yang sering dikaitkan dengan kelebihan ketentuan dan Metropolitan. Dalam perbincangan seterusnya, makalah ini akan membicarakan aspek-aspek ketidakseimbangan diskursiviti dan kewujudan modal simbolik yang dijanakan dengan cara ini dalam wahana dan kelebihan Metropolitan serta kedudukan dalam bidang tertentu. Titik tumpu rujukan perbincangan ini adalah dengan menggunakan sosiologi bahasa yang dikaryakan tentang identiti kaum India Malaysia.

Majoriti kaum India Malaysia berasal dari keturunan yang bersusur-galur dari pendatang yang meninggalkan kawasan persisiran pantai India Selatan pada kurun ke-sembilan belas terutamanya untuk membebaskan diri dari masalah kebuluran dan desakan hidup yang menekan keadaan sosio-ekonomi mereka; dan pelarian ini ketara dipengaruhi oleh khabar tentang peluang pekerjaan di ladangladang, projek-projek pembinaan jalan raya dan jalan keretapi yang menjadi keutamaan untuk harapan baru di Semenanjung Tanah Melayu ketika itu. Persoalan-persoalan tentang peristiwa sejarah dan kewujudan pengalaman sosiologi dibaca dan dibuat penilaian sebagai keutamaan dalam bidang kajian sejarah, ekonomi dan seterusnya secara predominan dibaca dan ditaakul dalam bidang sejarah, ekonomi dan sosio-politik. Hasil penerbitan sering kali diletakkan sebagai penghasilan ilmu pengetahuan tentang masyarakat Tamil Malaysia berdasarkan bukti-bukti empirikal. Namun, andainya dihimbau sosiologi bahasa yang ditulis tentang kaum India di Malaysia, kita akan mendapati bahawa pendatang India ke Tanah Melayu secara berterusan digambarkan sebagai komoditi dan mangsa penghambaan kapitalis penjajah. Ini merupakan respon langsung kepada peranan mereka dari sudut ekonomi. Sering diperkatakan tentang amalan pengambilan pekerja, corak penempatan, petunjuk usaha sama rantau atau komposisi etnolinguistik dan yang lebih penting, cara masyarakat India memberikan sumbangan kepada ekonomi kapitalis British di Tanah Melayu. Perkaraperkara ini sering dipermudahkan walaupun ada pendapat seperti yang 
dinyatakan oleh JanMohamed (1985) yang menggelarnya kognitif perancangan serampang dua mata penjajah (63). Dalam konteks sosiologi penanda etnik masyarakat Tamil Malaysia, kekuatan arus yang dijana oleh serampang ini kelihatan seolah-olah menjuruskan para penulis kepada dua sudut pandang kesarjanaan yang berbeza. Sudut pandang pertama ialah disebabkan pengulangan tentang kaum India di Malaysia (lebih tepat merujuk kepada kaum Tamil di Malaysia) sebagai mangsa keadaan yang akan kekal selamanya di luar kawalan mereka. Yang kedua ialah kelompok yang terperangkap dalam arus yang menjurus kepada kemewahan spiritual yang ritualistik. Kedua-duanya meletakkan mereka kepada apa yang dikatakan oleh Said (1978) sebagai gagasan tetap Orientalisme, terutamanya dari sudut pendapat sarjana barat tentang "peralihan dari tempat asal ke situasi reputasi kesarjanaan merupakan sumber seseorangan itu dikenali dalam catatan sejarah Orientalisme” (Said 2003 [1978]: 164).

Dinamik hegemoni salahsilah kaum India Malaysia dapat disusur galur melalui contoh-contoh yang akan dibincangkan. Pakar antropologi kontemporari Amerika, Andrew C Willford, yang berpusat di Global Utara, mendapat kelebihan dari modal budaya hasil kajian etnografik beliau dan sebuah hasil karya penerbitan beliau adalah tentang masyarakat Tamil Malaysia sebagai sebahagian daripada masyarakat terpinggir di Global Selatan. Sekiranya dikaji dinamik diskursif jaringan semantik yang terpapar dalam pilihan tajuk-tajuk dua jilid karya beliau tentang kaum ini, serta sebagai penulis makalah, tanda-tanda Orientalistik dari sudut kosa kata, perumpamaan dan gaya representasi menjadi sangat ketara malahan kehebatan modal simbolik yang dilihat juga sangat jelas. Setiap judul diungkap dengan cukup baik tentang Tamil Malaysia dalam penjelasan oleh kedua-dua pendapat yang berbeza ini. Dalam karya "Weapons of the meek": Ecstatic ritualism and strategic ecumenism among Tamil Hindus in Malaysia" (Willford 2002) dialogik setiap penanda linguistik dapat dilihat dengan ketara dalam hal yang menarik perhatian banyak pihak ini. Penanda-penanda ini menjadi senjata tetapi mempunyai ciri-ciri kelembutan di mana jaringan semantik menidakkan kuasa kelompok masyarakat tertentu seperti Tamil Malaysia. Sebaliknya, kuasa bererti kepercayaan dan kesetiaan dalam beragama, kelihatan tidak ketara. Makna rujukan jelas menunjukkan kegagalan dunia material, yang ditekankan melalui jaringan yang sangat cenderung kepada penafian. Willford terus menghasilkan penulisan dari data yang dikutip melalui kajian lapangan tentang masyarakat Tamil Malaysia, iaitu sebuah buku penerbitan universiti Metropolitan, juga dari hasil berjudul nuansa serampang mata, "Cage of freedom: Tamil identity and the ethnic fetish in Malaysia” (Willford 2006). Aspirasi kepada kebebasan muncul tidak benar-benar bebas kerana identiti hanyalah sekadar yang telah ditetapkan. Selain itu semiotik visual kulit buku tersebut juga menarik kerana ia memaparkan anak-anak tangga di sebuah kuil Hindu yang terkenal, dengan 
penganut yang sedang beribadat sewaktu sambutan Thaipusam iaitu pemujaan terhadap dewa Murugan. Pengiktirafan terletak hanya pada agama untuk kalangan masyarakat Tamil Malaysia. Satu dekad kemudian, Willford menghasilkan sebuah lagi buku, di bawah penerbit Metropolitan, dengan judul bernuansa yang sama "Tamil dan Pencarian Keadilan: Sejarah dan Pengiktirafan di Ladang di Malaysia (Willford 2015) disertai kulit buku yang menunjukkan kaum India Malaysia melakukan ibadat keagamaan yang dipaparkan melalui pakaian dan kali ini dalam suasana di pendalaman, dengan jalan kecil tanah merah sebagai latar belakang kulit buku. Sekiranya dilihat kedua-dua karya ini secara keseluruhan, akan jelas kelihatan bahawa gambaran-gambaran ini sarat dengan nuansa perwakilan wacana, diwarnai oleh kehendak subjektif pengumpulan ilmu pengetahuan tentang perkara utama hasil karya penulisan tersebut, dengan itu sangat berpersepsikan struktur mental (Bourdieu 1989, p.18), iaitu sosok diskursif. Seperti mana wacana karya Willford dapat diterangkan sebagai perkara utama semantik keadilan dari satu sudut manakala dari satu sudut lain pula menandakan spiritual keagamaan sosok kaum India Malaysia, karya-karya ini menjadi intipati subjektif dalam pengkisahan yang disampaikan oleh seorang antropologi. Inilah sebenarnya yang mengaitkan karya-karya ini dalam penerbitan budaya secara artistik dengan tumpuan pokok persoalan yang sama, iaitu teks-teks kesusateraan.

Sekiranya seperti mana yang dinyatakan oleh Arjun Appadurai (2005 , p.52), bentuk baru etnografi sewajarnya "memaparkan impak halangan terhadap bayangan sumber-sumber kehidupan dan pengalaman di sesuatu tempat" maka naratif kesusasteraan boleh memainkan peranan yang signifikan, terutamanya melalui penglibatan dialogik dengan bahan karya dalam lompangan dan rekahan yang dinafikan oleh bidang-bidang kajian lain, dengan tujuan mencari fakta dan angka serta data setiap sesuatu itu. Kesahan visi sosok kesusasteraan dan hubungan sosio-budaya masih menjadi perkara utama isu-isu perkembangan kemanusiaan sejak sekian lama seperti mana sesebuah cerita rakyat. Namun, nuansa pelbagai hierarki bahasa simbolik sering mempersendakan ketentuan dan ini menyebabkan kegagalan kesepaduan dialog pelbagai bidang kajian.

Sebagai kesimpulan, dibandingkan dua perenggan memori dan untung nasib kelas pekerja kaum India Malaysia untuk menyatakan pemetaan yang sama dalam sosok diskursif seperti yang dibincangkan. Yang pertama adalah daripada jilid terkini karya Willford tentang masyarakat Tamil Malaysia, manakala petikan yang kedua adalah daripada sebuah novel separa-autobiografi oleh seorang daripada perintis kesusasteraan India Malaysia, KS Maniam:

Pemimpin masyarakat, P. Palanisamy menyatakan kekecewaan apabila saya dan Naga menemu bual beliau pada tahun 2006. Palanisamy kecewa kerana satu perbicaraan yang 
melibatkan pertelingkahan dalam perebutan antara pekerja ladang Bukit Jalil dan kerajaan tempatan. Beliau menyatakan bahawa generasi baharu pegawai di Dewan Bandaran tidak memahami tentang kesusahan dan cabaran yang dihadapi oleh masyarakat pekerja ladang sejak bertahun-tahun lamanya, malahan tidak memahami tentang pengorbanan dan sumbangan mereka kepada tanah perladangan. Para pegawai ini juga tidak tahu tentang janjijanji yang ditabur kepada pekerja ladang sejak dahulu. (Willford 2014: 1)

Dia membahagikan masanya untuk mencari rezeki berjual vadai dengan kereta sorong kecil dan juga berulang-alik ke pejabat Dewan Bandaran untuk membuat rayuan pemilikan tanah kerana tanah itu telah didudukinya sejak sekian lama dan dia berhak mendapatnya.

"Saya sudah sebati di situ," katanya kepada saya. "apabila saya mati nanti, tentu sekali roh saya tidak akan tenang."

Namun dia tidak ada sebarang bukti bertulis, sekadar sedikit keyakinan dan kesetiaan yang semakin diraguinya. Rumah-rumah di situ termasuk rumahnya sendiri mulai dirobohkan. Bumbung rumah, alang dan rentung kebakaran kelihatan seperti maut yang lebih ganas merobek kehidupan Periathai setiap kali aku ke sana. Semakin kurang pula kini aku berkunjung ke sana. Periathai enggan keluar dari rumahnya kerana khuatir rumahnya terus ranap kalau dia tiada di rumah. (Maniam [1981] 1993).

Kedua-dua petikan ini mempunyai matlamat yang sama iaitu menyampaikan kekecewaan dan ketiadaan bukti-bukti di atas kertas sebagai kesahihan hak milik tanah. Novel K.S. Maniam berlatarkan zaman Tanah Melayu prakemerdekaan dan pertama kali diterbitkan pada tahun 1981, manakala pengkisahan etnografik yang ditulis oleh Willford dikaryakan pada zaman kontemporari Malaysia di era alaf baru. Sungguh pun demikian, tidak ada satu pun rujukan karya K.S Maniam dalam penulisan Willford. Inilah antara dialektik yang ingin diketengahkan oleh makalah ini melalui kesarjanaan baharu kajian budaya separa alternis dalam mengkaji masyarakat kelas pekerja kaum India, demi menangani cabaran-cabaran hegemoni diskursif dan keunggulan pengkaryaan dalam lingkungan kesarjanaan. Hakikatnya, perbincangan pelbagai disiplin perlu melibatkan perkaitan antara bidang. Apabila terdapat persamaan tertentu sewajarnyalah perkaitan ini dijalin agar dapat dipaparkan kehidupan masyarakat India di Malaysia yang dipinggirkan, dan sewajarnya juga nuansa pihak-pihak yang terbabit diberi perhatian termasuk bantahan terhadap kuasa tertentu dan keperluan di luar jangkaan realiti kehidupan.

\section{References}

Appadurai, Arjun. 2005. Modernity at large: Cultural dimensions of globalization. Minneapolis: $\mathrm{U}$ of Minnesota Press.

Bourdieu, Pierre. 1989. Social space and symbolic power. Sociological Theory 7(1). 14-25. 
Canagarajah, A. Suresh. 1996. "Nondiscursive” requirements in academic publishing, material resources of periphery scholars, and the politics of knowledge production. Written Communication 13(4). 435-472.

JanMohamed, Abdul R. 1985. The economy of Manichean allegory: The function of racial difference in colonialist literature. Critical Inquiry 12(1). 59-87.

Maniam, Krishnan S. 1993 [1981]. The return. London: Skoob Books.

Northrup, David. 1995. Indentured labor in the age of imperialism, 1834-1922. Cambridge: Cambridge University Press.

Said, Edward W. 2003 [1978]. Orientalism: Western conceptions of the orient. Harmondsworth: Penguin.

Sandhu, Kernial S. 1969. Indians in Malaya: Some aspects of their immigration and settlement (1786-1957). Cambridge: Cambridge University Press.

Tupas, Ruanni \& Rani Rubdy. 2015. Introduction: From world Englishes to unequal Englishes. In Tupas, Ruanni (ed.), Unequal Englishes the politics of Englishes today, 1-17. Basingstoke: Palgrave Macmillan.

Willford, Andrew C. 2002. "Weapons of the meek": Ecstatic ritualism and strategic ecumenism among Tamil Hindus in Malaysia. Identities: Global Studies in Culture and Power 9(2). 247-280.

Willford, Andrew C. 2006. Cage of freedom: Tamil identity and the ethnic fetish in Malaysia. Ann Arbor: University of Michigan Press.

Willford, Andrew C. 2015. Tamils and the haunting of justice: History and recognition in Malaysia's plantations. Honolulu: University of Hawai'i Press. 